\title{
FORUM
}

\section{The case for 'bottom-up' pest management}

\author{
Grant Norbury \\ Landcare Research, PO Box 282, Alexandra, New Zealand \\ (Email: Norburyg@landcareresearch.co.nz)
}

Published online: 8 June 2017

\begin{abstract}
The introduction of some animal and plant pest species in New Zealand has facilitated the establishment and success of other introduced pest species. Classic examples include rodents and rabbits, which have provided prey for a number of introduced mammalian predator species. Control of these introduced predators in New Zealand has historically focussed on removing them directly by lethal means. This approach suffers from density-dependent population responses that accelerate population recovery at low population densities. I suggest adopting an ecologically-based approach to pest control that breaks the interactive linkages between invasive mammalian pests at high trophic levels and the other introduced species that they rely on as their primary food resource. Some of these primary food species are, in turn, affected by land management practices and land-use policy. Removing the primary food resource for introduced pests at high trophic levels should, in theory, weaken the density-dependent responses that reduce the impact of lethal control. This 'bottom-up' form of pest control has the added advantage of reducing pest impacts at lower trophic levels. A greater emphasis on bottom-up pest management that targets lower trophic levels could greatly enhance current tactical approaches that focus directly on pests at higher trophic levels. Examples of where this approach could assist management of introduced pests in New Zealand and overseas are discussed.
\end{abstract}

Keywords: ecologically-based pest management; plant-herbivore relationships; predator-prey relationships

\section{Conventional pest control}

Plant and animal pests are a drain on New Zealand's economy, costing up to NZ\$3.3 billion per year (or $1.86 \%$ of GDP) in control and production losses for the primary sector alone (Giera \& Bell 2009). Although pest eradication is possible on offshore islands, ongoing control is currently the only tool on 'mainland' (North and South Island) sites. Typically, pest control focuses directly on removal of the target species by lethal means. This approach suffers from density-dependent population responses that accelerate population recovery at low densities. Such density-dependent responses include enhanced survival of residual target animals and high immigration (Byrom 2002; Lazenby et al. 2014; Lieury et al. 2015). The stronger the density-dependent responses, the greater the speed of recovery and the greater frequency of follow-up control required to suppress populations. In this paper I explore another pest management approach that could supplement conventional removal of pests.

\section{Bottom-up pest interactions}

New Zealand's vertebrate pest guild is highly inter-dependent. One important feature of the predator guild on the mainland is its dependence on other introduced mammalian pests as the primary food resource. For example, high mustelid (Mustela spp.) and cat (Felis catus) populations are driven 'bottom-up' by abundant introduced rodents (Rattus spp., Mus musculus) and rabbits (Oryctolagus cuniculus), leading to hyperpredation of native prey species (Ruscoe et al. 2006). By comparison, the opposite effect, the 'top-down' effect of predators on introduced prey, is generally weak on the New Zealand mainland (Blackwell et al. 2003; Ruscoe et al. 2011; Norbury \& Jones 2015). The bottom-up control of these systems poses the question of whether pest management strategies are more effective if focussed on the primary driver of pest populations - in other words, controlling pests at high trophic levels by controlling other pest species that they rely on for their primary food. I do not suggest that this wider ecological approach replaces conventional control. Targeting pests directly at high trophic levels will always be the primary focus, but I do argue that a more sustainable, and potentially more effective, solution to management of introduced mammalian pests should include greater focus on bottom-up control. Examples of systems that are amenable to this approach are outlined below and presented schematically in Figure 1.

\section{Land management-rabbit-predator interactions}

Modelling of pest eradications on islands suggests that predator eradication should precede eradication of introduced primary prey (Bode et al. 2015). I argue the opposite for pest control on the New Zealand mainland. One of the best examples of a bottom-up driven predator system here is the rabbit-predator relationship (Fig. 2). The population size, habitat use, and diet composition of ferrets (Mustela furo) and cats in dry grass/ shrubland systems of the South Island are driven largely by the abundance of rabbits (Murphy et al. 2004; Cruz et al. 2013; Norbury \& Jones 2015; Recio et al. 2015). In North Island forests adjacent to pastures that support rabbits, ferrets kill adult kiwi (Robertson et al. 2011; Robertson \& de Monchy 2012). The Department of Conservation (DOC) often controls rabbits in and around conservation reserves not only to reduce grazing impacts, but also to protect species that are vulnerable 

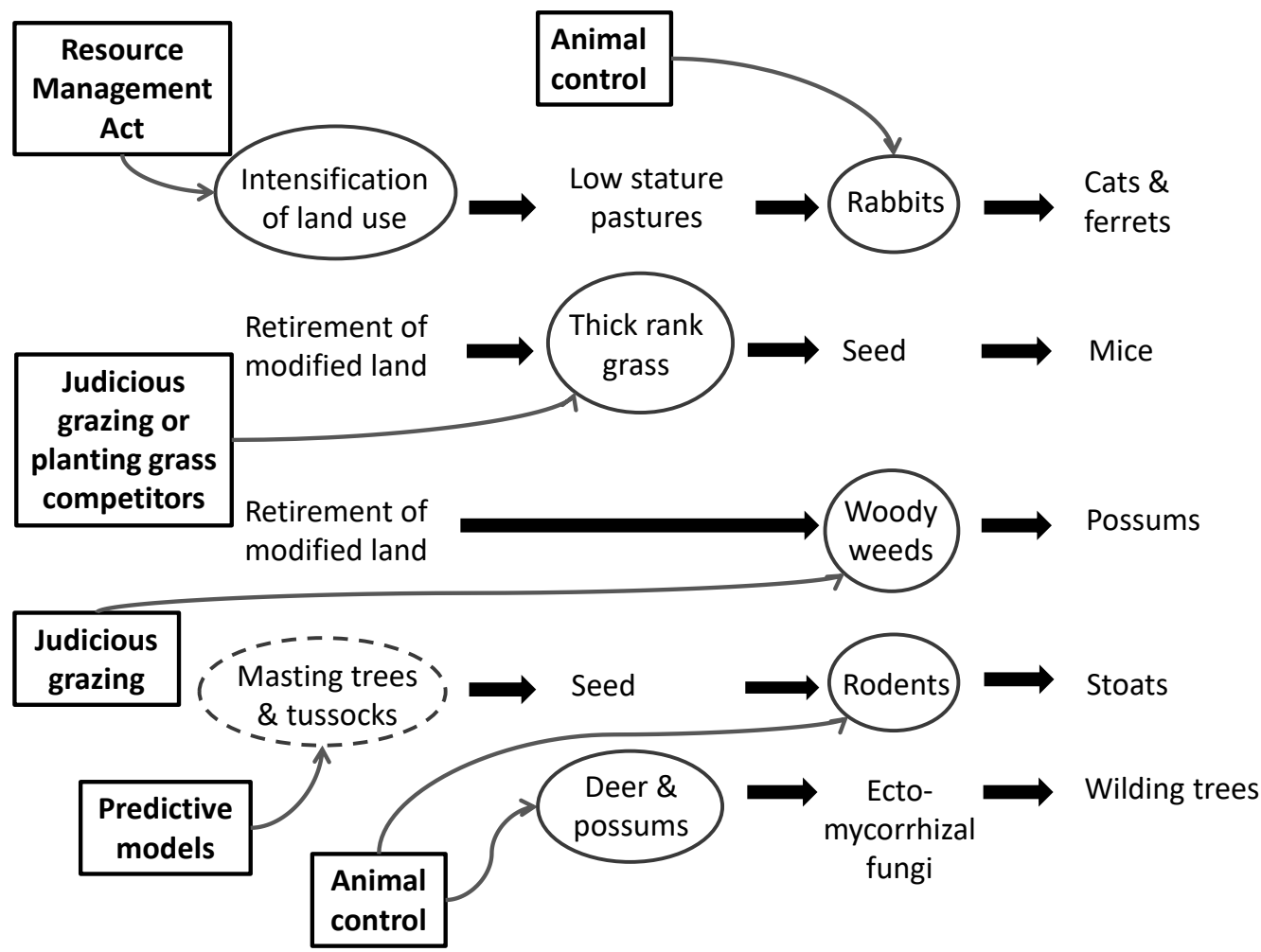

Figure 1. Examples of bottom-up driven pest systems in New Zealand. Bottom-up interventions are possible at multiple levels shown here. Interventions (boxes) at lower levels (circles) target fundamental processes that drive pest abundance, thereby providing longer-term, more sustainable benefits than interventions at higher levels. Intervening with tree and tussock masting (dashed circle) is not possible, but it is possible to predict when masting is likely to occur.
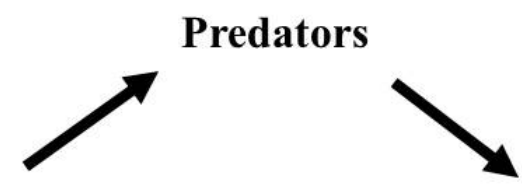

Rabbits
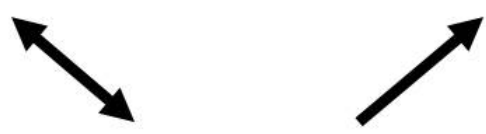

Vegetation structure

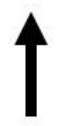

\section{Land use}

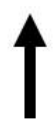

\section{Resource Management Act}

Figure 2. Key social and biological processes in a rabbit-predator system that allow for a bottom-up approach to conservation of vulnerable indigenous species, such as lizards. Land-use policy guided by the Resource Management Act 1991 ultimately affects lizard conservation, both directly through habitat alteration, and indirectly through trophic linkages among the pest guild. to predation. One of the risks of this approach is predators switching their diet to indigenous prey species immediately following large rabbit declines (Norbury 2001; Murphy et al. 2004). However, this is usually a temporary risk that, if necessary, can be offset with predator control before predator numbers decline (e.g. up to 12 months later), as was the case when rabbit populations were reduced after rabbit haemorrhagic disease was introduced to New Zealand (Aikman 1997).

There are also economic incentives to adopt bottom-up control of predators in this system. Rabbit control using aerial poisoning costs approximately NZ\$70 per ha every 5 or so years, whereas the maintenance cost of trapping predators intensively (mixture of daily checks of leg-hold traps and weekly checks of lethal traps) is approximately NZ\$60 per ha every year (Norbury et al. 2014a).

Furthermore, numbers of ferrets, cats and rabbits could be controlled by management actions targeted even further down the food chain in this system. Rabbit abundance is affected by vegetation structure and composition. Woody ecosystems and tall tussock grasslands that are modified by clearing and burning to enhance agricultural productivity result in short green pastures (preferred rabbit food) within mosaics of intact vegetation (rabbit shelter). This enrichment of food and shelter favours rabbits (Norbury et al. 2013; Whitehead et al. 2014), and is used as a form of habitat management to restore rabbit numbers in their native Iberian Peninsula (Lombardi et al. 2007; Ferreira et al. 2014). At Macraes Flat in eastern Otago, a large lizard reserve containing tall tussock and regenerating shrubland is surrounded by agricultural land that is fertilised and grazed by livestock. Rabbits and predators are abundant in these surrounding lands, and migration into the reserve is 
the primary source of predators, particularly cats (Norbury \& Anderson 2015). Unless controlled, predators have detrimental effects on the indigenous lizards (Oligosoma spp.) within the reserve (Reardon et al. 2012). This is an example of 'landscape supplementation' (sensu Dunning et al. 1992) of invasive species leading to 'hyperpredation' (sensu Smith \& Quin 1996; Courchamp et al. 2000) of indigenous prey species and detrimental conservation outcomes.

These trophic interactions demonstrate the important ecological role of land management in mitigating predation of indigenous species in some ecosystems. A key question is how can farmland adjacent to conservation reserves be managed in a productive way, but at the same time minimise the impacts of rabbits and predators? This question has never been adequately addressed in New Zealand. In addition, the indirect effects of landscape supplementation on indigenous biodiversity are usually unrecognised in land-use policy. The Resource Management Act 1991 is the legislation designed to minimise the adverse effects of land management. However, local government authorities charged with enacting the Act rarely, if ever, consider the wider ecological perspectives described here when considering consent applications. Consents are regularly issued for land developments that happen to favour rabbits (see Dymond et al. (2017) for ongoing loss of intact tussock grassland habitat), thereby repeating the cycle of landscape supplementation and hyperpredation of indigenous species.

\section{Land management-seed-rodent interactions}

Other ecosystems that could potentially benefit from bottom-up pest management are modified lowland ecosystems undergoing restoration by removal of livestock. These ecosystems are usually well-endowed with introduced pasture species that produce large seed crops every year. Removal of livestock results in a super-abundance of seed, which boosts mouse populations (Norbury et al. 2013). Mice are also predators of indigenous invertebrates and lizards (Newman 1994; Towns \& Elliott 1996; Lettink \& Cree 2006; Hoare et al. 2007; Norbury et al.2014b). Some researchers have implied that well-intentioned restoration projects involving cessation of livestock grazing have led to lizard declines due to greater predation by mice or by top-order predators that have benefited from more mice (Newman 1994; Hoare et al. 2007; Knox et al. 2012). Recent experiments have confirmed the links between cessation of grazing, profusion of seed from introduced grasses, rodent increases, and elevated impacts on lizards (Knox et al. 2012; Norbury et al. 2013).

A bottom-up method of mitigating these impacts is to judiciously graze livestock to crop introduced grasses and therefore reduce seed production, perhaps combined with adding refuges for native species. Close monitoring would be required to ensure that the anticipated positive effects are balanced against the potentially negative effects of grazing. There may also need to be trade-offs of ecological values for particular sites, for example, by accepting increases in some species at the expense of others. Judicious grazing has been suggested for weed control elsewhere in the world, such as modified desert grasslands in California (Germano et al. 2012). This method is probably most practical over small ( $<100$ ha) areas, which is a suitable scale for conserving local invertebrate and lizard populations. The problem with this approach is that it locks managers into perpetuating a livestock-introduced grass system. A preferable approach would be to gradually replant indigenous species to outcompete the grasses (see Reay \& Norton 1999).

\section{Woody weed-possum interactions}

Brushtail possums (Trichosurus vulpecula) are another pest species amenable to bottom-up pest management. Woody weeds such as briar (Rosa rubiginosa) and willow (Salix fragilis) are important components of possum diet in dry grass/ shrubland ecosystems (Glen et al. 2012), and woody vegetation is favoured possum habitat (Whitehead et al. 2014; Rouco et al. 2017). Removal of woody weeds is a bottom-up approach to possum control but it is very expensive (NZ\$300-600 per ha for herbicide application every 10-20 years) compared with conventional possum control (NZ\$4 per ha every few years). Nevertheless, it may be a more socially acceptable form of pest management in some circumstances, or it might be a useful add-on to integrate with direct control methods. Cessation of livestock grazing usually accelerates recruitment of woody weeds, which in turn facilitates possum numbers. Again, judicious use of livestock grazing to limit woody weed recovery is another bottom-up approach further down the food chain, although the same risks explained above will also apply here. An important question is whether habitat manipulation would reduce possum densities enough to break transmission of the disease they carry, bovine tuberculosis.

It should be clear from these examples that a bottom-up approach that reduces one pest species can have the opposite effect on others. For example, promoting habitat that is unfavourable for rabbits, such as dense shrubland or thick grass swards, may favour mice and possums; and conversely, grazing thick pastures to reduce seed and mice may favour rabbits. Grazing woody weeds to reduce possums may also hinder recovery of native shrublands. Therefore, the best bottom-up approach will depend on the conservation values managers wish to safeguard or promote. No single approach will necessarily fit all conservation objectives.

\section{Seed-rodent-stoat interactions}

Another example of a bottom-up predator-prey system in New Zealand, and perhaps the most damaging of all, is the rodentstoat (Mustela erminea) interaction in South Island beech forest (O’Donnell \& Phillipson 1996) and alpine tussock ecosystems (O’Donnell et al. 2016). Like the rabbit-predator system, stoats are driven bottom-up primarily by mice but also by rats (Wilson \& Lee 2010; Elliott \& Kemp 2016), which are themselves predators (or 'mesopredators') of indigenous species. Rats are targeted for control using aerially dispersed 1080 poison baits, and stoats are killed, secondarily, by consuming rat carcasses (Murphy et al. 1999) (aerial delivered bait-poison systems are currently unavailable for direct control of stoats). Stoat survival is further reduced by lack of food. This control system is somewhat consistent with the bottom-up approach advocated here and is sometimes used as a knock-down tool for predators early in simultaneous eradications of multiple species on islands (e.g. Dowding et al. 1999; Griffiths et al. 2015). Stoat control using aerial 1080 secondary poisoning during the 'Battle for our Birds' campaign (Elliott \& Kemp 2016) costs approximately NZ $\$ 21$ per ha whenever significant beech masting occurs. Maintenance costs of trapping stoats in the Murchison Mountains during a mast year (seven checks per year) is approximately NZ\$6 per ha, but this does not include NZ\$35 set-up costs per ha, and is not as effective as aerial 1080 at killing rats and possums (DOC, unpubl. data). While development of cost-effective technologies for landscape-scale control of rats is relatively advanced, the same cannot be said for mice on mainland New Zealand. Given the 
damaging effects of mice on indigenous species mentioned earlier, cost-effective mouse control should be a priority area for research and development.

At lower trophic levels, rats and mice are in turn driven bottom-up by episodic mass production of seed during mast events (Kelly et al. 2008). Mast-seed events lead to hyperpredation by rats, mice and stoats, applying enormous pressure on vulnerable indigenous prey species (Tompkins et al. 2013). These events cannot be prevented and so intervention is feasible only at the mesopredator and top-predator levels. However, they can be predicted (Kelly et al. 2013; Holland et al. 2015), enabling conservation authorities to prepare for the ensuing surfeit of predators (Elliott \& Kemp 2016).

\section{Herbivore-fungi-weed interactions}

Adifferent example from those above is an interaction between herbivores and wilding trees. The dung of red deer (Cervus elaphus) and brushtail possum contain ectomycorrhizal fungi that are mutualistic with wilding trees (Pinus contorta, Pseudotsuga menziesii) (Wood et al. 2015). Therefore, deer and possums could facilitate the spread and establishment of these wilding species. A bottom-up approach to wilding tree control may be to reduce deer and possum populations, or to restrict their movements between infected and uninfected areas (Dickie et al. 2016). Research is required to understand how effective this approach might be.

\section{Additional advantages of bottom-up pest management}

There are additional advantages of bottom-up pest management besides reducing pests at high trophic levels. Removal of lower-order pests reduces the impacts they themselves have on resources. Targeting rabbits has multiple advantages besides just reducing predator numbers: it helps restore indigenous plant communities and reduces agricultural damage (Norbury 1996; Norbury \& Norbury 1996; Scroggie et al. 2012). Controlling rodents to control stoats has the added advantage that rodents themselves are significant predators (and probably food competitors) of indigenous species (Innes et al. 1999; St Clair 2011; Knox et al. 2012). They also consume forest seedlings, which potentially alters forest succession and community structure (Campbell \& Atkinson 2002; Wilson et al. 2003). Controlling introduced pasture species and woody weeds has the added advantage of reducing competition with indigenous plant communities (Cuevas \& Zalba 2010). All of these impacts can be ameliorated by focussing control on these lower trophic levels.

Another significant advantage of bottom-up approaches that target low trophic levels is that some approaches do not involve killing pests (e.g. grazing or out-competing grasses that boost mice, or land management practices that disadvantage rabbits). These approaches avoid the ethical issues surrounding lethal control and strengthen the 'social license' (sensu Parkes et al. 2017) to manage pests.

\section{Overseas examples}

There are many examples overseas of bottom-up processes leading to undesirable impacts on species conservation. In Australia and Europe, bottom-up effects appear to dominate rabbit-predator interactions (Erlinge et al. 1984; Mutze et al. 1998; Holden \& Mutze 2002; Ferreras et al. 2011; Cooke 2012). Smith and Quin (1996) argue that rabbits led indirectly to declines in Australian native rodents through enhanced predation by introduced foxes (Vulpes vulpes). This assertion is supported by modelling (Pech \& Hood 1998) and by recent evidence of recovery of some Australian mammals following rabbit declines with rabbit haemorrhagic disease virus (Pedler et al. 2016).

Intensification of natural gas development in Wyoming, USA, has led to increases in rodent populations and subsequent declines in avian nest survival (Hethcoat \& Chalfoun 2015). Forest fragmentation, timber harvesting, and agricultural development in Canada have benefitted moose (Alces alces), white-tailed deer(Odocoileus virginianus), and their predators (wolf Canis lupus and cougar Puma concolor), leading to declines in their secondary prey species, woodland caribou (Rangifer tarandus caribou) and mule deer (Odocoileus hemionus) (Kinley \& Apps 2001; Robinson et al. 2002; Wittmer et al. 2007; Latham et al. 2011). Changing land management practices to offset these responses is potentially more costeffective than targeting the immediate problem species. Wittmer et al.'s (2013) review of mammalian interactions in North and South America concluded that an integrated control system was a better strategy for conserving rare prey species than either predator control alone, or primary prey control alone. Changing land management practices to reduce agricultural damage is referred to as 'ecologically-based pest management' (National Research Council 1996). There are numerous published examples for rodents (see Singleton et al. 1999), including reducing damage through crop management and removal of rodent refuge (Brown et al. 2004, 2006).

\section{Conclusion}

I have argued that improved conservation outcomes can be achieved by integrating control of pests at high trophic levels with disruption of bottom-up processes that maintain them. Removing the primary food resource of these pests should, in theory, weaken density-dependent population responses that accelerate population recovery at low densities. This bottom-up approach is consistent with Mack et al.'s (2000) and Zavaleta et al.'s (2001) view that pest management is most effective when it employs a long-term, ecosystem-wide strategy rather than a tactical approach focused on individual species. The long-term sustainability of control programmes that target bottom-up driven pests, in particular large-scale aspirational projects like 'Predator Free New Zealand'(Russell et al. 2015), may depend on greater attention to this approach. Research that addresses the cost-effectiveness of integrating bottom-up pest management with conventional approaches is required.

\section{Acknowledgements}

Thanks to Roger Pech, Al Glen, John Innes, Andrea Byrom, Bruce Warburton, Dan Tompkins, James Russell, Mick Clout, George Perry, and an anonymous referee for comments on earlier drafts of this manuscript, Lindsay Wilson and Peter Morton for predator control costs, and Anne Austin for editing. This work was funded by Core funding for Crown research institutes from the Ministry of Business, Innovation and Employment's Science and Innovation Group (contracts CO9X0505 and CO9X0909). 


\section{References}

Aikman H 1997. Department of Conservation response plan for use in the event of an outbreak of rabbit calicivirus disease (RCD). Threatened Species Occasional Publication 10. Wellington, Department of Conservation. 135 p.

Blackwell GL, Potter MA, McLennan JA, MinotEO 2003. The role of predators in ship rat and house mouse population eruptions: drivers or passengers? Oikos 100: 601-613.

Bode M, Baker CM, Plein M 2015. Eradicating down the food chain: optimal multispecies eradication schedules for a commonly encountered invaded island ecosystem. Journal of Applied Ecology 52: 571-579.

Brown PR, Davies MJ, Singleton GR, Croft JD 2004. Can farm-management practices reduce the impact of house mouse populations on crops in an irrigated farming system? Wildlife Research 31: 597-604.

Brown PR, Tuan NP, Singleton GR, Ha PT, Hue DT, Tan TQ, Van Tuat N, Jacob J, Müller WJ 2006. Ecologically based management of rodents in the real world: applied to a mixed agroecosystem in Vietnam. Ecological Applications 16: 2000-2010.

Byrom AE 2002. Dispersal and survival of juvenile feral ferrets Mustela furo in New Zealand. Journal of Applied Ecology 39: 67-78.

Campbell DJ, Atkinson IAE 2002. Depression of tree recruitment by the Pacific rat (Rattus exulans Peale) on New Zealand's northern offshore islands. Biological Conservation 107: 19-35.

Cooke BD 2012. Rabbits: manageable environmental pests or participants in new Australian ecosystems? Wildlife Research 39: 279-289.

Courchamp F, Langlais M, Sugihara G 2000. Rabbits killing birds: modelling the hyperpredation process. Journal of Animal Ecology 69: 154-164.

Cruz J, Glen AS, Pech RP 2013. Modelling landscape-level numerical responses of predators to prey: the case of cats and rabbits. Plos One 8: e73544.

Cuevas YA, Zalba SM 2010. Recovery of native grasslands after removing invasive pines. Restoration Ecology 18: 711-719.

Dickie IA, Nuñez MA, Pringle A, Lebel T, Tourtellot SG, Johnston PR 2016. Towards management of invasive ectomycorrhizal fungi. Biological Invasions 18: 33833395.

Dowding JE, Murphy EC, Veitch CR 1999. Brodifacoum residues in target and non-target species following an aerial poisoning operation on Motuihe Island, Hauraki Gulf, New Zealand. New Zealand Journal of Ecology 23: 207-214.

Dunning JB, Danielson BJ, Pulliam HR 1992. Ecological processes that affect populations in complex landscapes. Oikos 65: 169-175.

Dymond JR, Shepherd JD, Newsome PF, Belliss S 2017. Estimating change in areas of indigenous vegetation cover in New Zealand from the New Zealand Land Cover Database (LCDB). New Zealand Joumal of Ecology 41: 56-64.

Elliott G, Kemp J 2016. Large-scale pest control in New Zealand beech forests. Ecological Management \& Restoration 17: 200-209.

Erlinge S, Goransson G, Hogstedt G, Jansson G, Liberg O, Loman J, Nilsson IN, von Schantz T, Sylven M 1984. Can vertebrate predators regulate their prey? American Naturalist 123: 125-133.
Ferreira C, Touza J, Rouco C, Díaz-RuizF, Fernandez-de-Simon J, Ríos-Saldana CA, Ferreras P, Villafuerte R, DelibesMateos M 2014. Habitat management as a generalized tool to boost European rabbit Oryctolagus cuniculus populations in the Iberian Peninsula: a cost-effectiveness analysis. Mammal Review 44: 30-43.

Ferreras P, Travaini A, Zapata SC, Delibes M 2011. Short-term responses of mammalian carnivores to a sudden collapse of rabbits in Mediterranean Spain. Basic and Applied Ecology 12: 116-124.

Germano DJ, Rathbun GB, Saslaw LR 2012. Effects of grazing and invasive grasses on desert vertebrates in California. The Journal of Wildlife Management 76: 670-682.

Giera N, Bell B 2009. Economic costs of pests to New Zealand. A report prepared by Nimmo-Bell for MAF Biosecurity New Zealand. Technical Paper No. 2009/31. Wellington, MAF Biosecurity New Zealand.

Glen AS, Byrom AE, Pech RP, Cruz J, Schwab A, Sweetapple PJ, Yockney I, Nugent G, Coleman M, Whitford J 2012. Ecology of brushtail possums in a New Zealand dryland ecosystem. New Zealand Journal of Ecology 36: 29-37.

Griffiths R, BuchananF, BroomeK, Neilsen J, BrownD, Weakley M 2015. Successful eradication of invasive vertebrates on Rangitoto and Motutapu Islands, New Zealand. Biological Invasions 17: 1355-1369.

Hethcoat MG, Chalfoun AD 2015. Towards a mechanistic understanding of human-induced rapid environmental change: a case study linking energy development, nest predation and predators. Journal of Applied Ecology 52: 1492-1499.

Hoare JM, Adams LK, Bull LS, Towns DR 2007. Attempting to manage complex predator-prey interactions fails to avert imminent extinction of a threatened New Zealand skink population. Journal ofWildlife Management 71: 1576-1584.

Holden C, Mutze G 2002. Impact of rabbit haemorrhagic disease on introduced predators in the Flinders Ranges, South Australia. Wildlife Research 29: 615-626.

Holland EP, James A, Ruscoe WA, Pech RP, Byrom AE 2015. Climate-based models for pulsed resources improve predictability of consumer population dynamics: outbreaks of house mice in forest ecosystems. Plos One 10: e0119139.

Innes J, Hay R, Flux I, Bradfield P, Speed H, Jansen P 1999. Successful recovery of North Island kokako (Callaeas cinerea wilsoni) populations, by adaptive management. Biological Conservation 87: 201-214.

Kelly D, Koenig W, Liebhold A 2008. An intercontinental comparison of the dynamic behavior of mast seeding communities. Population Ecology 50: 329-342.

Kelly D, Geldenhuis A, James A, Holland P, Plank MJ, Brockie RE, Cowan PE, Harper GA, Lee WG, Maitland MJ, Mark AF, Mills JA, Wilson PR, Byrom AE 2013. Of mast and mean: differential-temperature cue makes mast seeding insensitive to climate change. Ecology Letters 16: 90-98.

Kinley TA,Apps CD 2001. Mortality patterns in a subpopulation of endangered mountain caribou. Wildlife Society Bulletin (1973-2006) 29: 158-164.

Knox CD, Cree A, Seddon PJ 2012. Direct and indirect effects of grazing by introduced mammals on a native, arboreal gecko (Naultinus gemmeus). Journal of Herpetology 46: 145-152.

Latham ADM, Latham MC, McCutchen NA, Boutin S 2011. Invading white-tailed deer change wolf-caribou dynamics in northeastern Alberta. The Journal of Wildlife Management 75: 204-212. 
Lazenby BT, Mooney NJ, Dickman CR 2014. Effects of lowlevel culling of feral cats in open populations: a case study from the forests of southern Tasmania. Wildlife Research 41: 407-420.

Lettink M, Cree A 2006. Predation, by the feral house mouse (Mus musculus), of McCann's skinks (Oligosoma maccanni) constrained in pitfall traps. Herpetofauna 36: 61-62.

Lieury N, Ruette S, Devillard S, Albaret M, Drouyer F, Baudoux B, Millon A 2015. Compensatory immigration challenges predator control: an experimental evidencebased approach improves management. The Journal of Wildlife Management 79: 425-434.

Lombardi L, Fernández N, Moreno S 2007. Habitat use and spatial behaviour in the European rabbit in three Mediterranean environments. Basics and Applied Ecology 8: 453-463.

Mack RN, Simberloff D, Lonsdale WM, Evans H, Clout M, Bazzaz FA 2000. Biotic invasions: causes, epidemiology, global consequences, and control. Ecological Applications 10: 689-710.

Murphy EC, Robbins L, Young JB, Dowding JE 1999. Secondary poisoning of stoats after an aerial 1080 poison operation in Pureora Forest, New Zealand. New Zealand Journal of Ecology 23: 175-182.

Murphy EC, Keedwell RJ, Brown KP, Westbrooke I 2004. Diet of mammalian predators in braided river beds in the central South Island, New Zealand. Wildlife Research 31: 631-638.

Mutze G, Cooke B, Alexander P 1998. The initial impact of rabbit hemorrhagic disease on European rabbit populations in South Australia. Journal of Wildlife Diseases 34: 221-227.

National Research Council 1996. Ecologically based pest management: new solutions for a new century. Washington DC, National Academy Press.

Newman DG 1994. Effects of a mouse, Mus musculus, eradication programme and habitat change on lizard populations of Mana Island, New Zealand, with special reference to McGregor's skink, Cyclodina macgregori. New Zealand Journal of Zoology 21: 443-456.

Norbury D 1996. The effect of rabbits on conservation values. Science for Conservation 34. Wellington, Department of Conservation. $32 \mathrm{p}$.

Norbury G 2001. Conserving dryland lizards by reducing predator-mediated apparent competition and direct competition with introduced rabbits. Journal of Applied Ecology 38: 1350-1361.

Norbury G, Anderson D 2015. Macraes Flat predator model. Unpublished Landcare Research Contract Report LC2248, prepared for Department of Conservation.

Norbury G, Jones C 2015. Pests controlling pests: does predator control lead to greater European rabbit abundance in Australasia? Mammal Review 45: 79-87.

Norbury DC, Norbury GL 1996. Short-term effects of rabbit grazing on a degraded short-tussock grassland in Central Otago. New Zealand Journal of Ecology 20: 285-288.

Norbury G, Byrom A, Pech R, Smith J, Clarke D, Anderson $\mathrm{D}$, Forrester G 2013. Invasive mammals and habitat modification interact to generate unforeseen outcomes for indigenous fauna. Ecological Applications 23: 1707-1721.

Norbury G, Hutcheon A, Reardon J, Daigneault A 2014a. Pest fencing or pest trapping: a bio-economic analysis of costeffectiveness. Austral Ecology 39: 795-807.
Norbury G, van den Munckhof M, Neitzel S, Hutcheon AD, Reardon JT, Ludwig K 2014b. Impacts of invasive house mice on post-release survival of translocated lizards. New Zealand Journal of Ecology 38: 322-327.

O’Donnell CFJ, Phillipson SM 1996. Predicting the incidence of mohua predation from the seedfall, mouse, and predator fluctuations in beech forests. New Zealand Journal of Zoology 23: 287-293.

O’Donnell CFJ, Weston KA, Monks JM 2016. Impacts of introduced mammalian predators on New Zealand's alpine fauna. New Zealand Journal of Ecology 41: 1-22.

Parkes JP, Nugent G, Forsyth DM, Byrom AE, Pech RP, Warburton B, Choquenot D 2017. Past, present and two potential futures for managing New Zealand's mammalian pests. New Zealand Journal of Ecology 41: 151-161.

Pech PR, Hood GM 1998. Foxes, rabbits, alternative prey and rabbit calicivirus disease: consequences of a new biological control agent for an outbreaking species in Australia. Journal of Applied Ecology 35: 434-453.

Pedler RD, Brandle R, Read JL, Southgate R, Bird P, Moseby KE 2016. Rabbit biocontrol and landscape-scale recovery of threatened desert mammals. Conservation Biology 30: 774-782.

Reardon JT, Whitmore N, Holmes KM, Judd LM, Hutcheon AD, Norbury G, Mackenzie DI 2012. Predator control allows critically endangered lizards to recover on mainland New Zealand. New Zealand Journal of Ecology 36: 141-150.

Reay SD, Norton DA 1999. Assessing the success of restoration plantings in a temperate New Zealand forest. Restoration Ecology 7: 298-308.

Recio MR, Seddon PJ, Moore AB 2015. Niche and movement models identify corridors of introduced feral cats infringing ecologically sensitive areas in New Zealand. Biological Conservation 192: 48-56.

Robertson HA, de Monchy PJM 2012. Varied success from the landscape-scale management of kiwi Apteryx spp. in five sanctuaries in New Zealand. Bird Conservation International 22: 429-444.

Robertson HA, Colbourne RM, Graham PJ, Miller PJ, Pierce RJ 2011. Experimental management of brown kiwi Apteryx mantelli in central Northland, New Zealand. Bird Conservation International 21: 207-220.

Robinson HS, Wielgus RB, Gwilliam JC 2002. Cougar predation and population growth of sympatric mule deer and white-tailed deer. Canadian Journal of Zoology 80: 556-568.

Rouco C, Norbury GL, Anderson DP 2017. Movements and habitat preferences of pests help to improve population control: the case of common brushtail possums in a New Zealand dryland ecosystem. Pest Management Science 73: 287-294.

Ruscoe WA, Norbury G, Choquenot D 2006. Trophic interactions among native and introduced animal species. In: Allen RB, Lee WG eds. Biological invasions in New Zealand. Berlin, Heidelberg, Springer. Pp. 247-263.

Ruscoe WA, Ramsey DSL, Pech RP, Sweetapple PJ, Yockney I, Barron MC, Perry M, Nugent G, Carran R, Warne R, Brausch C, Duncan RP2011. Unexpected consequences of control: competitive vs. predator release in a four-species assemblage of invasive mammals. Ecology Letters 14: 1035-1042.

Russell JC, Innes JG, Brown PH, Byrom AE 2015. PredatorFree New Zealand: conservation country. BioScience 65: 520-525. 
Scroggie MP, Parkes JP, Norbury G, Reddiex B, Heyward R 2012. Lagomorph and sheep effects on vegetation growth in dry and mesic grasslands in Otago, New Zealand. Wildlife Research 39: 721-730.

Singleton GR, Hinds LA, Leirs H, Zhang Z 1999. Ecologicallybased rodent management. Canberra, Australian Centre for International Agricultural Research.

Smith AP, Quin DG 1996. Patterns and causes of extinction and decline in Australian conilurine rodents. Biological Conservation 77: 243-267.

St Clair JJH 2011. The impacts of invasive rodents on island invertebrates. Biological Conservation 144: 68-81.

Tompkins DM, Byrom AE, Pech RP2013. Predicted responses of invasive mammal communities to climate-related changes in mast frequency in forest ecosystems. Ecological Applications 23: 1075-1085.

Towns D, Elliott G 1996. Effects of habitat structure on distribution and abundance of lizards at Pukerua Bay, Wellington, New Zealand. New Zealand Journal of Ecology 20: 191-206.

Whitehead A, Byrom A, Clayton R, Pech R 2014. Removal of livestock alters native plant and invasive mammal communities in a dry grassland-shrubland ecosystem. Biological Invasions 16: 1105-1118.

Editorial board member: Tom Etherington

Received 26 March 2017; accepted 10 May 2017
Wilson DJ, Lee WG 2010. Primary and secondary resource pulses in an alpine ecosystem: snow tussock grass (Chionochloa spp.) flowering and house mouse (Mus musculus) populations in New Zealand. Wildlife Research 37: 89-103.

Wilson DJ, Lee WG, Webster RA, Allen RB 2003. Effects of possums and rats on seedling establishment at two forest sites in New Zealand. New Zealand Journal of Ecology 27: $147-155$.

Wittmer HU, McLellan BN, Serrouya R, Apps CD 2007. Changes in landscape composition influence the decline of a threatened woodland caribou population. Journal of Animal Ecology 76: 568-579.

Wittmer HU, Serrouya R, Elbroch LM, Marshall AJ 2013. Conservation strategies for species affected by apparent competition. Conservation Biology 27: 254-60.

Wood JR, Dickie IA, Moeller HV, Peltzer DA, Bonner KI, Rattray G, Wilmshurst JM 2015. Novel interactions between non-native mammals and fungi facilitate establishment of invasive pines. Journal of Ecology 103: 121-129.

Zavaleta ES, Hobbs RJ, Mooney HA 2001. Viewing invasive species removal in a whole-ecosystem context. Trends in Ecology and Evolution 16: 454-459. 